\title{
Corrigendum: Slow cooling and highly efficient extraction of hot carriers in colloidal perovskite nanocrystals
}

Mingjie Li, Saikat Bhaumik, Teck Wee Goh, Muduli Subas Kumar, Natalia Yantara, Michael Grätzel, Subodh Mhaisalkar, Nripan Mathews \& Tze Chien Sum

Nature Communications 8:14350 doi: 10.1038/ncomms14350 (2017); Published 8 Feb 2017; Updated 25 May 2017

The original version of this Article contained a typographical error in the first sentence of the abstract in which 'Shockley-Queisser' was incorrectly given as 'Schottky-Queisser'. This has now been corrected in both the PDF and HTML versions of the Article.

\footnotetext{
(c) (i) This work is licensed under a Creative Commons Attribution 4.0 International License. The images or other third party material in this article are included in the article's Creative Commons license, unless indicated otherwise in the credit line; if the material is not included under the Creative Commons license, users will need to obtain permission from the license holder to reproduce the material. To view a copy of this license, visit http://creativecommons.org/licenses/by/4.0/
}

(C) The Author(s) 2017 